\title{
Pseudomonas nitroreducens
}

National Cancer Institute

\section{Source}

National Cancer Institute. Pseudomonas nitroreducens. NCI Thesaurus. Code C124365.

A species of gram-negative, motile, non-spore-forming, rod-shaped, aerobic soil bacteria in the family Pseudomonadaceae first isolated from oil brine in Japan. P. nitroreducens is negative for beta-galactosidase and hydrolysis of gelatin. 